\title{
Human leptospirosis in the Federal District, Brazil, 2011-2015: eco-epidemiological characterization
}

\author{
Ivanildo de Oliveira Correia Santos ${ }^{[1]}$, Marina Frota de Albuquerque Landi ${ }^{[2]}$, \\ Laurício Monteiro Cruz ${ }^{[1]}$, Maria Isabel Rao Bofill[ ${ }^{[1]}$, Divino Eterno dos Santos ${ }^{[1]}$, \\ Eduardo Maurício Mendes de Lima ${ }^{[2]}$ and Márcio Botelho de Castro ${ }^{[2]}$
}

[1]. Departamento de Vigilância Ambiental, Secretaria da Saúde, Administração do Distrito Federal, Brasília, DF, Brasil.

[2]. Faculdade de Agronomia e Veterinária, Universidade de Brasília, Brasília, DF, Brasil.

\begin{abstract}
Introduction: Leptospirosis is an infectious disease that affects more than 5,000 people per year in Brazil. The Federal District (FD) lacks epidemiological studies of human leptospirosis and presents concerning rates of this disease, especially considering its lethality. Methods: Seventy-nine autochthonous human cases of leptospirosis between 2011 and 2015 were analyzed, with the probable infection location serving as a basis for the collection and analysis of the environmental and epidemiological variables. Results: The incidence of the disease ranged from 0.68-13.39 per 100,000 inhabitants in 21 of the 31 administrative regions that compose the FD. The local profile of human leptospirosis was predominantly associated with urban areas during the rainy season, population access to the sewage network, the treated water network, and the public garbage collection service. The vast majority of cases had a strong association with synanthropic rodents at the infection sites. Conclusions: In order to prevent and control potentially lethal human leptospirosis infection, the eco-epidemiological characterization of this disease is a valuable tool for public policies of prevention, control, and surveillance. In addition to population awareness, the systematized control of synanthropic rodents could be the main health action to reduce the incidence of this disease in the FD.
\end{abstract}

Keywords: Leptospirosis. Synanthropic rodents. Eco-epidemiology. Environment.

\section{INTRODUCTION}

Leptospirosis is one of the most important types of global zoonosis, affecting affecting over one million people per year, worldwide ${ }^{1,2}$. It is a febrile infectious disease caused by bacteria of the genus Leptospira. The serovars Leptospira icterohaemorraghiae and Leptospira copenhagueni are mainly responsible for severe cases of this disease in humans ${ }^{3,4}$.

Domestic, synanthropic, and wild animals are considered the main reservoirs and are responsible for the permanence of foci of the infection. Moreover, bacterium is present in the urine of infected animals and under favorable conditions can remain viable in the environment for months ${ }^{1,4-6}$.

The common environmental risk for human leptospirosis in tropical countries, such as Brazil, is associated with poor social and hygiene conditions in rural areas, as well as the outskirts of urban areas. The vulnerable population lives and works in these areas with scarce resources, low levels of social and health care, lack of basic sanitation, and environmental factors, such

Corresponding author: Dr. Márcio Botelho de Castro.

e-mail: mbcastro@unb.br

Received 7 August 2017

Accepted 13 December 2017 as high rainfall and recurrent floods during the rainy season ${ }^{5,7-10}$.

The Ministry of Health (MS) identifies an average of 5,000 confirmed human leptospirosis cases per year ${ }^{11}$, placing the disease as one of the most relevant diseases among febrilehemorrhagic syndromes in Brazil ${ }^{12}$. In the Federal District (FD) of Brazil, a considerable number of new cases of the disease occur annually. However, the knowledge about regional aspects and characteristics favorable to its emergence are scarce.

Due to the complex scenario associated with the epidemiology of leptospirosis, this work aims to characterize the eco-epidemiological environment, seasonality, and spatial distributions of human cases of the disease in the FD of Brazil. The establishment of information and regional factors involved in human leptospirosis could guide the planning of public actions and policies for the prevention, control, and surveillance of this disease.

\section{METHODS}

The environmental characterization of autochthonous human cases of leptospirosis in the FD of Brazil, from 2011 to 2015, was conducted by consulting the databases of the Directorate of Epidemiological and Environmental Surveillance in Health of the Federal District, in accordance with the notifications of the system [Sistema de Informação de Agravos de Notificação 
(SINAN)] of the Ministry of Health ${ }^{11}$. Data banks of the Planning Company of the Federal District ${ }^{13}$ were consulted for the geographic characterization of the FD.

The temporal cut-off for inclusion of the cases was determined from the day of the first symptoms presented by the patients, considering the incubation period of the disease from 0-30 days ${ }^{5}$. The location of the residence and probable infection place (PIP) of each patient was determined through the Global Geographic Location System [Global Positioning System (GPS)].

The cases of this study were confirmed in agreement with the parameters of the World Health Organization and the Ministry of Health for human leptospirosis by clinical, epidemiological, and laboratory criteria ${ }^{12}$. The information used was selected exclusively from cases of the disease in individuals that reside in the FD and with autochthony confirmed by epidemiological and environmental investigation. Patients with leptospirosis that resided in the FD with indefinite PIP (absence or multiple PIPs) were excluded from this study. The incidence per 100,000 inhabitants of human leptospirosis throughout the FD was calculated in each of its administrative regions.

The variables listed and collected in the PIP of each human case, by environmental and epidemiological investigation included: georeferenced point, location in urban or rural area, presence of allotments, invasion areas or other land-based irregularities, accessibility to treated water, collection and treatment of sewage, and regular public collection of domestic waste. Other epidemiological data investigated were the presence of livestock production, wild animals and companion animals (dogs and cats), traces of synanthropic rodents (feces, trails, gnawing, spots), water collection (stream, lake, river, dam), predominant vegetation cover, agricultural crops, contact with sewage, contact with garbage/rubble, and exposure to events, such as flooding, at the time of infection. The Network of the National Institute of Meteorology [Instituto Nacional de Meteorologia (INMET) provided the data used for the calculation of the average monthly rainfall in the FD in the studied period. Quantum Geographic Information System (GIS) 2.0.1 ${ }^{\circledR}$ software was used for the preparation of the map of the incidence of the disease.

\section{RESULTS}

The Federal District occupies a territory of $5,789 \mathrm{~km}^{2}$ in the Central Brazilian region, with the current geopolitical division composed of 31 administrative regions. It presents plateaus of soft topography with cerrado vegetation and a tropical climate with rivers crossing its territory. The FD houses the federal capital, Brasília, which, a little longer than half a century after its foundation, maintains a population that is about to reach 3 million inhabitants ${ }^{13}$.

In the FD, between 2011 and 2015, 79 autochthonous human cases of leptospirosis were registered, with epidemiological and environmental investigation, as well as confirmation of the probable infection place (PIP). The incidence of the disease in the region ranged from $0.68-13.39$ per 100,000 inhabitants. The incidence of human leptospirosis in the 10 administrative regions with the highest indexes is shown in Table 1. In the entire territory of the FD, between 2011 and 2015, PIPs of the disease were recorded in 21 out of 31 administrative regions (Figure 1).

Human leptospirosis in the FD occurred predominantly in urban areas with adequate sanitary conditions (77.2\%), access to the sewage network (50.1\%), and access to treated water (57\%) and public garbage collection services (63.3\%) (Figure 2). During the analyzed period, the disease occurred more frequently during the rainy season, with $79.8 \%$ of cases occurring between October and April (Figure 3).

TABLE 1: Incidence of human leptospirosis per 100,000 inhabitants in FD and in the 10 administrative regions with the highest indices of the disease, $2011-2015$.

\begin{tabular}{lccc}
\hline Administrative regions & Cases & Population (million) & Incidence \\
\hline Brazlândia & 7 & 52,287 & 13.39 \\
Sobradinho & 8 & 68,551 & 11.67 \\
Lago Norte & 3 & 29,505 & 10.17 \\
Cruzeiro & 3 & 33,539 & 8.94 \\
Núcleo Bandeirante & 2 & 25,072 & 7.98 \\
SCIA (Estrutural, Cidade do Automóvel) & 3 & 39,015 & 7.69 \\
Vicente Pires & 4 & 72,879 & 5.49 \\
Riacho Fundo & 2 & 40,098 & 4.99 \\
Lago Sul & 1 & 24,406 & 4.10 \\
Brasília & 8 & 214,529 & 3.73 \\
\hline Federal District & 79 & 2,852 & 2.76 \\
\hline
\end{tabular}

FD: Federal District; SCIA: Setor Complementar de Indústria e Abastecimento. 


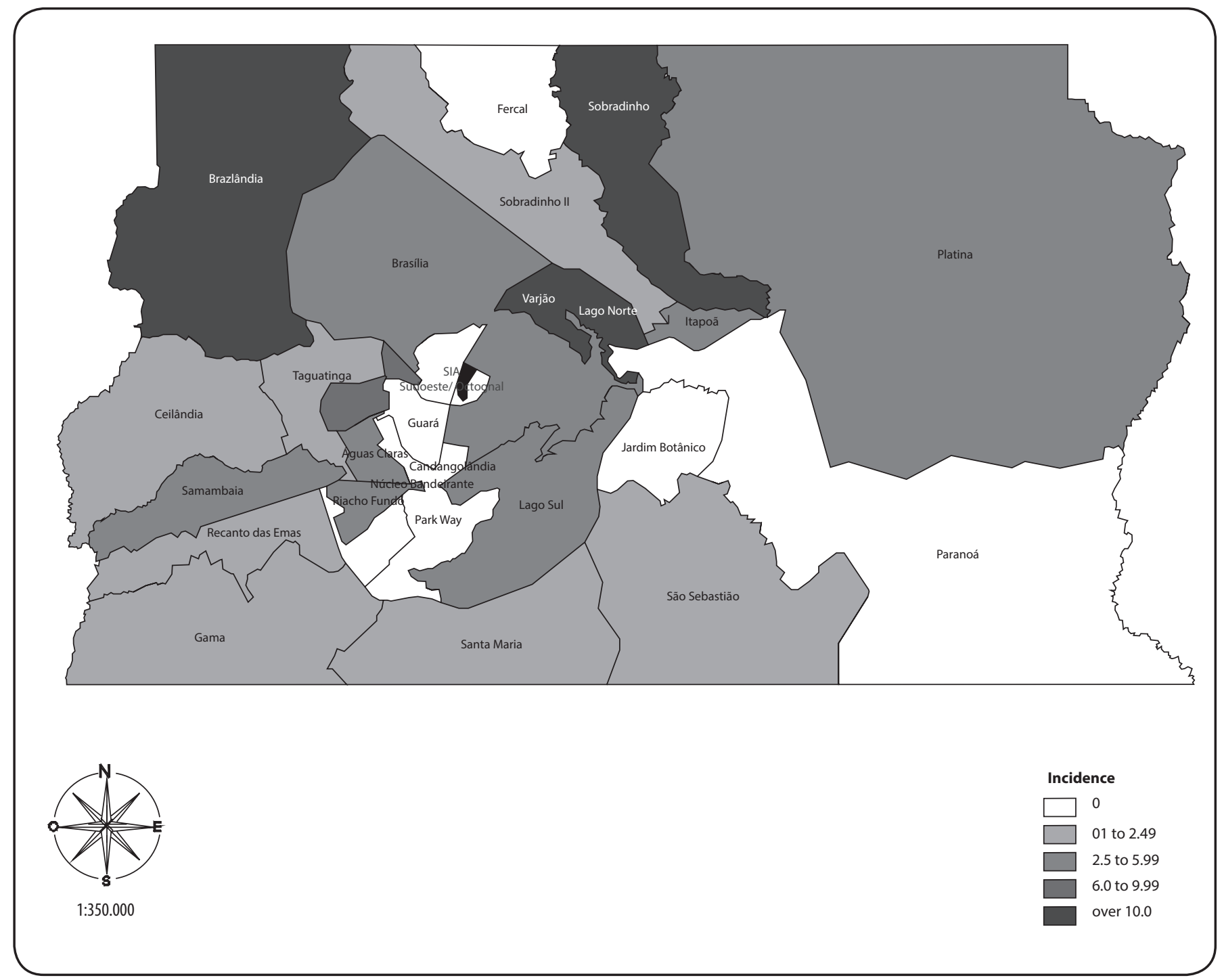

FIGURE 1 - Incidence of human leptospirosis per 100,000 inhabitants in the administrative regions of the FD between 2011 and 2015 . FD: Federal District.

The disease presented a strong association with the visualization, contact, or traces of synanthropic rodents at infection sites (93.7\%). The presence of companion animals in $48.1 \%$ of PIPs was higher than wild animals $(25.3 \%)$ and livestock production $(22.8 \%)$, which were observed almost exclusively in the rural areas of the FD.

In the $\mathrm{FD}, 43 \%$ of patients with human leptospirosis were infected in environments with proximity to vegetation of cerrado or gallery forests and $31.6 \%$ of cases occurred in areas with allotments, invasion areas, or other land-based irregularities.

\section{DISCUSSION}

Human leptospirosis is considered one of the main infectious diseases of great public health concern in the FD of Brazil. This analysis of the eco-epidemiological characteristics of this disease in the FD highlights the differences between other regions previously characterized as at high risk for leptospirosis in Brazil $1^{9,14}$.
The incidence of leptospirosis in the evaluated period is among the highest of the Brazilian federal units ${ }^{11}$. This finding reinforces the need for public health policies and management in the FD regarding leptospirosis and other acute febrile diseases (hantavirus, yellow fever, and influenza) in addition to dengue fever, which are considered one of the most important public health issues in Brazil ${ }^{4,15}$. Despite leptospirosis having less morbidity than dengue fever in the FD, the lethality of the disease is higher than infections caused by the dengue virus ${ }^{11}$. Another point to consider is that human leptospirosis in the FD may not have all cases reported due to the failure to recognize and diagnose the disease by the public health network ${ }^{4,5}$.

Human leptospirosis was detected in 21 of the 31 administrative regions of the FD. This shows that the highrisk environments for leptospirosis are found throughout the territory, contradicting the idea of restricted areas for disease occurrence $^{2,6}$. However, the absence of PIPs in some regions during the studied period does not exclude the existence of 
risk environments in these areas and even the occurrence of infection, due to undetected cases ${ }^{4}$.

Among the 10 administrative regions with the highest incidence of human leptospirosis in the FD, 7 have a high human development index ${ }^{16}$. This observation contradicts the common-sense explanation that the occurrence of the disease is associated with low-income populations and poor sanitary environmental conditions, such as those found in the outskirts of large cities and metropolitan areas ${ }^{2,8,9,17}$. In the FD, there exists an environment not yet characterized for human infection which does not match the socioeconomic profile of the areas usually associated with this disease ${ }^{2}$.

The profile of human leptospirosis in the FD was predominantly urban, which matches the eco-epidemiological profile of the disease in other federal units of Brazil, where most of the population lives in large urban centers ${ }^{5-8,18}$. However, it should be considered that the regional distribution of these populations are predominantly urban and that the limits of separation associated with rural areas are often indistinct within a given region ${ }^{13}$. The characterization of urban and rural environments in the eco-epidemiological study of diseases are not standardized, as different criteria might be used to define them ${ }^{9}$.

Regarding the sanitary aspects, most PIPs in the FD presented collection and treatment of sewage, access to treated water, and regular collection of waste. In Brazil, the unavailability of these 3 elements that define sanitation in many cases is closely related to the disorderly growth of urban areas, forcing the population to find irregular housing in the outskirts and suburbs, and potentially exposing them to the risks of infection by various diseases ${ }^{8,9,18}$. Sanitation and behavioral risk factors are usually considered strongly associated with leptospirosis, although their impact is rarely investigated ${ }^{19}$.

In this study, what distinguishes the FD is the frequent formation of irregular urban conglomerates for years, without

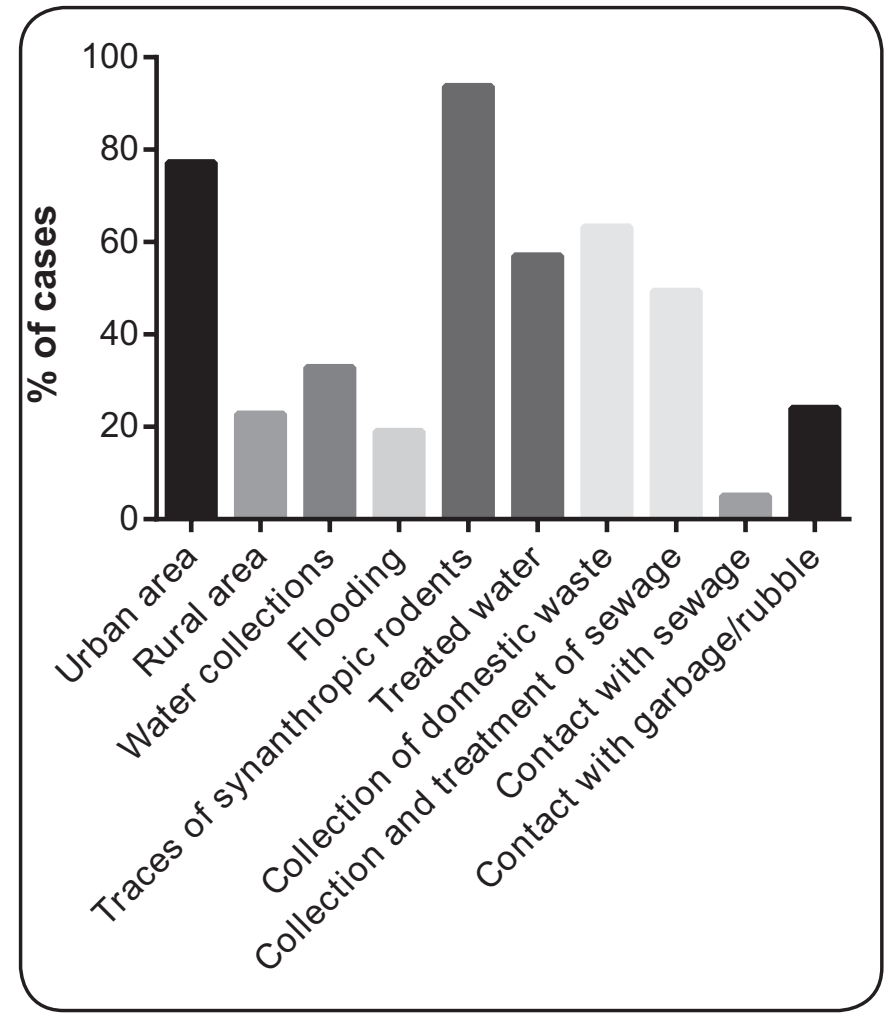

FIGURE 2 - Frequency of eco-epidemiological data related to cases of human leptospirosis in the FD between 2011 and 2015. FD: Federal District.

a necessarily low income, that present all aspects referred to as basic sanitation ${ }^{5}$. However, the risks of human infection with leptospirosis should not be credited only to these conditions. Poverty, as well as geographic and climate conditions, are often associated with the social and environmental situations that increase risk of human exposures to sources of infection ${ }^{2}$.

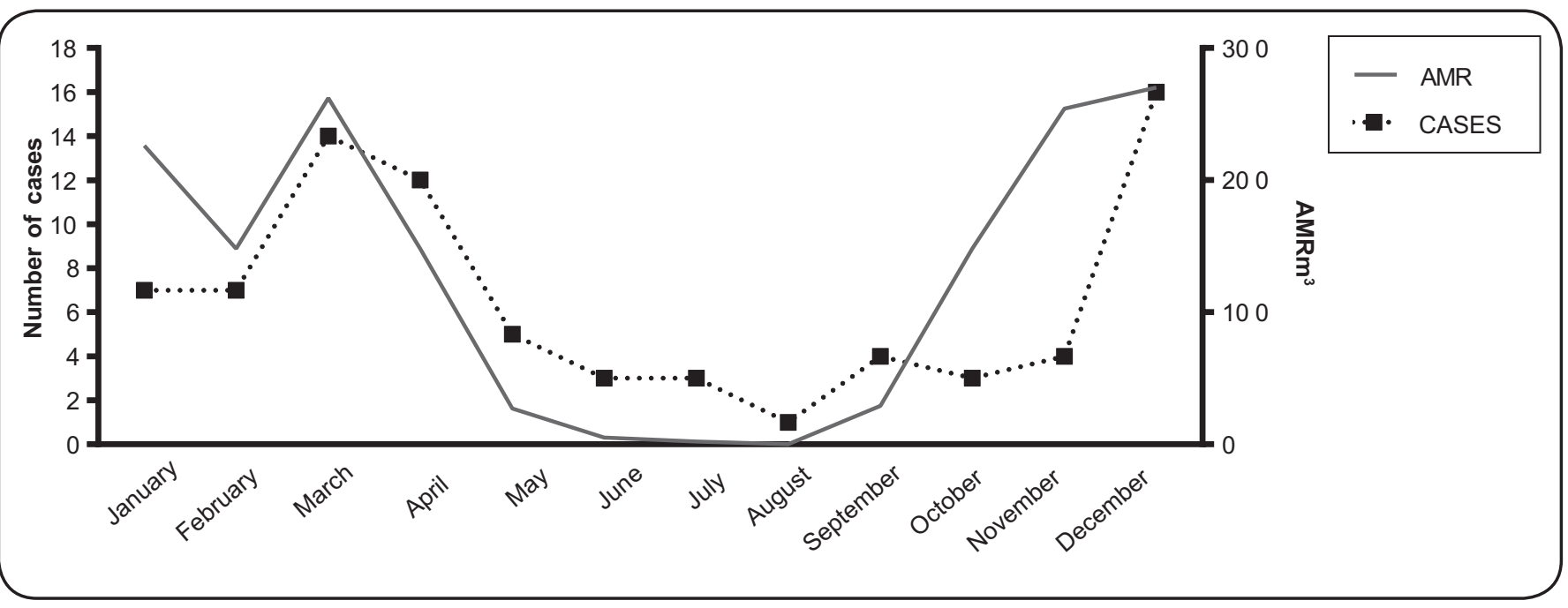

FIGURE 3 - Monthly distribution of cases of human leptospirosis and average monthly rainfall in the FD between 2011 and 2015 . AMR: average monthly rainfall; FD: Federal District. 
Although urban slum environments are increasingly important settings for leptospirosis transmission, less urbanized areas are associated with higher infection rates than urban settings. Therefore, there should be an association between lower urbanization and poverty ${ }^{2,5}$. In the FD, there is a contradiction to the previously mentioned association, since most cases were not linked to urban slum environments and poverty. However it was not possible to detect other socio-environmental risk factor associated with the infection in this study.

The FD presents a well-defined period of rainfall from October to April, and drought between May and September ${ }^{20}$. The increase in infection during the rainy season and the lower number of cases in dry periods reinforces the idea of direct exposure of humans via water collection or situations resulting from the accumulation of water ${ }^{11}$. However, patients were exposed to rainwater or floodplains in only $19 \%$ of the analyzed cases. This result points to situations in the FD where infection occurred in a humid but not flooded environment, as commonly related to the epidemiology of the disease $\mathrm{e}^{7,10}$.

It is important to note that human leptospirosis in the FD occurred with a lower prevalence during periods of drought. Negligence in the detection of human leptospirosis during periods of drought ${ }^{10}$ and the viability of bacterium in favorable environments in all months and seasons $s^{4,7}$ are important factors that could justify these observations in the FD.

Water collections such as rivers, streams, or lagoons represent approximately $1 / 3$ of the environment with leptospirosis infection in the present study. Found in all of the rural areas and in a few urban areas, these water collections had a weak association with human infections in the FD. There is one exception in the case of Lake Paranoá, located in the urban area of the FD, which represented the infection environment of all cases occurring in the North Lake administrative region (third largest incidence of the disease in the FD). Lake Paranoá, however, does not represent, as a whole, a problem or inherent risk situation. There are specific places along its shoreline used for fishing and other leisure activities such as swimming, diving, or sports that may increase the risk for infection ${ }^{19}$. Dumping points for rainwater, sewage, and garbage treatment plants close to Lake Paranoá deserve attention for environmental monitoring ${ }^{9,17}$.

The availability of water, food, and shelter create conditions for the development and maintenance of synanthropic rodents ${ }^{18,22}$. In this sense, in both urban and rural environments, the presence of companion, wild, and production animals could favor the proximity of synanthropic rodents in the environment and would increase the risk of infection due to inadequate management of livestock and the storage of food and agricultural products.

Synanthropic rodents are recognized as the main reservoirs for human and animal leptospirosis ${ }^{6,9,21}$. The high index of PIPs with traces or visualization of these rodents reinforces the importance of these animals in the epidemiology of the disease. However, other species of companion, production, or wild animals should also be considered as potential reservoirs ${ }^{6,18,22}$. In this study, it was not possible to identify the importance or risk of other animal species in the transmission of leptospirosis in FD.
Regarding the presence of animals in the PIPs, all cases in rural areas of the FD happened near production or wild animals, but not necessarily in direct contact with people. It is important to consider the presence of wild animals is not restricted to rural areas. Although an increased risk of human infection in these situations was not detected, the environment of parks and gardens and many ecological corridors strengthen the integration between urban, rural, and cerrado areas in the FD.

Dogs or cats were present in approximately half of the PIPs in the FD. However, it was not also possible to evaluate whether they presented a risk for infection. Contact with, or the presence of, companion animals in PIPs does not necessarily increase the risk of human infection, to the detriment of other situations and risk environments ${ }^{2,22}$.

The presence of plant cover in PIP environments was not a relevant factor in human leptospirosis in the analyzed period. However, vegetation densification is recognized as a shelter for synanthropic rodents, providing water and food supplies ${ }^{18}$, and may be a conditioning factor for the viability of the bacteria, which favor the maintenance of temperature and humidity ${ }^{6}$.

The characterization of the environment of human infection by a disease is of extreme importance for implantation, and even for evaluation, of the Health Surveillance Administrations. The present study identified the administrative regions with the highest incidence of the disease, the season of the greatest occurrence of infection, and highlights the direct or indirect exposure to synanthropic rodents as the main factors associated with the disease in the FD. In addition to awareness regarding preventive health measures, the systematized control of synanthropic rodents could be the main health action to reduce the incidence of this disease in the FD.

Despite the continental dimension and diversity of biomes, climates, altitudes, and cultures in Brazil, this work reinforces the importance of regional epidemiological studies as a tool for public health authorities to promote the control, prevention, and surveillance of human leptospirosis.

\section{Acknowledgments}

The authors acknowledge the Subsecretaria de Vigilância em Saúde, Secretaria de Estado de Saúde do Distrito Federal, Brasília for technical support.

\section{Conflict of interest}

The authors declare that there is no conflict of interest.

\section{REFERENCES}

1. Allan KJ, Biggs HM, Halliday JEB, Kazwala RR, Maro VP, Cleaveland S, et al. Zoonosis and a Paradigm for 'One Health' in Africa. PLoS Negl Trop Dis. 2015;14;9(9):e0003899.

2. Costa F, Hagan JE, Calcagno J, Kane M, Torgerson P, MartinezSilveira MS, et al. Global morbidity and mortality of leptospirosis: a systematic review. PLoS Negl Trop Dis. 2015;9(9):e0003898.

3. Daher EF, Lima RSA, Silva Júnior GB, Silva EC, Karbage NNN, Kataoka RS, et al. Clinical presentation of leptospirosis: a retrospective study of 201 patients in a metropolitan city of Brazil. Braz J Infect Dis. 2010;14(1):3-10. 
4. Fontes RM, Cavalcanti LPG, Oliveira ACA, Bezerra LFM, Gomes AMM, et al. A new possibility for surveillance: do we identify all cases of leptospirosis?. Rev Inst Med Trop. São Paulo. 2015;57(5):443-6.

5. Pelissari DM, Maia-Elkhoury ANS, Arsky MLN, Nunes ML. Revisão sistemática dos fatores associados à leptospirose no Brasil, 2000-2009. Epidemiol Serv Saúde. 2011;20(4):565-74.

6. Cipullo RI, Dias RA. Associação de variáveis ambientais à ocorrência de leptospirose canina e humana na cidade de São Paulo. Arq Bras Med Vet. 2012;64(2):363-70.

7. Monahan AM, Miller IS, Nally JE. Leptospirosis: risks during recreational activities. J Appl Microbiol. 2009;107(3):707-16.

8. Jesus MS de, Silva LA, Lima KMS, Fernandes OCC. Cases distribution of leptospirosis in City of Manaus, State of Amazonas, Brazil, 2000-2010. Rev Soc Bras Med Trop. 2012;45(6):713-16.

9. Araujo WN, Brooke F, Ribeiro GS, Reis RB, Felzemburgh RDM, Reis MG, et al. Knowledge, Attitudes, and Practices Related to Leptospirosis among Urban Slum Residents in Brazil. Am J Trop Med Hyg. 2013;88(2):359-63.

10. Guimarães RM, Cruz OG, Parreira VG, Mazoto ML, Vieira JD, Asmuset CIRF. Temporal analysis of the relationship between leptospirosis and the occurrence of flooding due to rainfall in the city of Rio de Janeiro, Brazil, 2007-2012. Ciência \& Saúde Coletiva. 2014;19(9):3683-92.

11. Ministério da Saúde (MS). Secretaria de Vigilância em Saúde. Indicadores e Dados Básicos para a Saúde. Brasília: MS; 2016. [updated 2016 September 21; cited 2016 Dec 7]. Available from: http://portalsaude.saude.gov.br/index.php/situacao-epidemiologicadados/

12. Albuquerque Filho APL, Araújo JG, Souza IQ de, Martins LC, Oliveira MI, Silva MJB, et al. Validation of a case definition for leptospirosis diagnosis in patients with acute severe febrile disease admitted in reference hospitals at the state of Pernambuco, Brazil. Rev Soc Bras Med Trop. 2011;44(6):735-9.

13. Companhia de Planejamento do Distrito Federal (CODEPLAN). Indicadores de Qualidade Ambiental e Urbana para o DF.
Brasília: CODEPLAN; 2015. [updated 2015 May 03; cited 2016 Dec 7]. Available from: http://www.codeplan.df.gov.br/images/ CODEPLAN/PDF/TD/TD_5_Indicadores_de_Qualidade_ Ambiental_e_Urbana_para_o_DF_2015.pdf

14. Soares TSM, Latorre MRDO, Laporta GZ, Buzzar MR. Análise espacial e sazonal da leptospirose no município de São Paulo, SP, 1998 a 2006. Rev Saúde Públ. 2010;44(2):283-91.

15. Dusi RM, Bredt A, Freitas DRC de, Bofill MIR, Silva JAM de, et al. Ten years of a hantavirus disease emergency in the Federal District, Brazil. Rev Soc Bras Med Trop. 2016;49(1):34-40.

16. Chediek J, Peral A, Neri MC, Chaves M. O índice de Desenvolvimento Humano Municipal Brasileiro: Atlas do Desenvolvimento Humano no Brasil. Brasília: PNUD Brasil; 2013. 96p.

17. Maciel EAP, Carvalho ALF, Nascimento SF, Matos RB, Gouveia E $\mathrm{L}$, Reis MG, et al. Household transmission of Leptospira infection in urban slum communities. PLoS Negl Trop Dis. 2008;2(1):154.

18. Vasconcelos CH, Fonseca FR, Lise MLZ, Arsky MLNS. Fatores ambientais e socioeconômicos relacionados à distribuição de casos de leptospirose no Estado de Pernambuco, Brasil, 2001-2009. Cad Saude Colet. 2012;20(1):49-56.

19. Mwachui MA, Crump L, Hartskeerl R, Zinsstag J, Hattendorf J. Environmental and Behavioural Determinants of Leptospirosis Transmission: A Systematic Review. PLoS Negl Trop Dis. 2015;17(9):e0003843.

20. Instituto Nacional de Meteorologia (INMET). Normas Climatológicas. [Internet]. Brasília: INMET; 2016. [updated 2016 April 05; cited 2016 Dec 7]. Available from: http://www.inmet.gov. br/portal/.

21. Santos AAN, Figueira CP, Reis MG dos, Costa F, Ristow P. Heterogenic colonization patterns by Leptospira interrogans in Rattus norvegicus from urban slums. Braz J Microbiol. 2015;46(4):1161-4.

22. Wasiński B, Dutkiewicz J. Leptospirosis-current risk factors connected with human activity and the environment. Ann Agric Environ Med. 2013;20(2):239-44. 